ADDENDUM.-Since this paper was submitted for publication a further 14 patients suffering from acute myelogenous leukaemia have been treated with daunorubicin and cytosine arabinoside. Eight had acute myeloblastic leukaemia, five had acute myelomonoblastic leukaemia, and one had acute promyelocytic leukaemia. Of these patients, nine have achieved complete remission. This brings the total number of treated patients to 37 , of whom 23 achieved complete remissions (62\%).

Requests for Reprints to be sent to Dr. D. Crowther, Department of Medicine, St. Bartholomew's Hospital, West Smithfield, London E.C.1, England.

\section{REFERENCES}

Beard, M. E. J., et al. (1970). British Medical fournal, 1, 191. Bergmann, W., and Feeney, R. J. (1951). Journal of Organic Chemistry, 16, 981.

Boiron, M., et al. (1969). Lancet, 1, 330.
Burchenal, J. H. (1970). Cancer Research. In press.

Capizzi, R. L., Summers, W. P., and Bertino, J. R. (1970). Proceedings of

the American Association for Cancer Research, 11, 14 .
Carey, R. W. (1970). Proceedings of the American Association for Cancer Research, 11, 15.

Di Marco, A. (1968). Acta Genetical Medical et Gemellologicae, 17, 102.

Ellison, R. R., et al. (1968). Blood, 32, 507.

Freireich, E. J., et al. (1970). Recent Results in Cancer Research, 30, 85.

Gee, T. S., Yu, K. P., and Clarkson, B. D. (1969). Cancer (Philadelphia), 23, 1019.

Grein, A., Spalla, C., Di Marco, A., and Canevazzi, G. (1963). Giornale di Microbiologia, 11, 109.

Groupe Coopérateur des Leucémies et Hématosarcomes (1969). European Fournal of Cancer, 5, 339.

Haghbin, M., et al. (1970). Proceedings of the American Association for Cancer Research, 11, 33.

Henderson, E. S. (1969). Seminars in Haematology, 6, 271.

Hewlett, J. S., et al. (1964). Cancer Chemotherapy Reports, 42, 27.

Hill, J. M., et al. (1969). Cancer Research, 29, 1574.

McElwain, T. J., and Hardisty, R. M. (1969). British Medical fournal, 4, 596.

Mathé, G., et al. (1969). Lancet, 1, 697.

\title{
Comparison of Coil and Kiil Dialysers
}

\author{
P. F. DOWN,* M.B., B.S., M.R.C.P. ; D. E. FARRAND,† ; S. E. WOOD, † S.R.N., Q.N. \\ H. A. LEE, $\$ M.B., B.SC., M.R.C.P.
}

British Medical fournal, 1970, 4, 517-521

ummary: To assess the comparative efficiency, safety, $S$ and cost of maintenance dialysis, the treatment of 13 patients with a Kiil dialyser (representing 1,477 hospital and 735 home lialyses) was compared with that of 11 patients using a coil dialyser (898 hospital and 396 home dialyses). Kiil and coil dialysers proved equally satisfactory from a medical standpoint and equally acceptable to the patients. The capital costs of home dialysis were considerably reduced without any threat to safety or efficiency. The running costs of coil dialysers approximate to those of Kiil dialysers.

\section{Introduction}

Regular haemodialysis has been practised for 10 years and the technique has been standardized in most units (Baillod et al., 1966; Shaldon, 1966; Scribner, 1967; Curtis et al., 1969). About 700 countercurrent dialysers of the Kiil type were being used for intermittent haemodialysis in the United Kingdom in 1968, with dialysate supplied by various automatic proportioning systems (Kulatilake, Vickers, and Shackman, 1969). Many of these dialysis systems are very expensive, so that with current resources only a minority of the patients who could benefit will receive treatment with maintenance haemodialysis (B.M.F., 1969). The high capital cost of the automatic proportioning and monitoring systems for dialysate delivery, together with the need for expert maintenance, has led us to revert to the original tank system.

Kiil type dialysers take a considerable time to prepare, so that the recent successful use of a disposable dialyser (Kulatilake et al., 1969) is a considerable advance. For similar reasons the disposable coil dialyser has obvious advantages, and we have compared this with the conventional Kiil dialyser with respect to efficiency, safety, and cost. This paper describes the results of our experience in Portsmouth,

- Research Assistant, Wessex Regional Renal Unit.

+ Senior Technician, Wessex Regional Renal Unit.

F Home Dialysis Administrator, Wessex Regional Renal Unit.

Consultant Physician, Portsmouth Group Hospitals; Physician, Wessex Regional Renal Unit, St. Mary's General Hospital, Portsmouth; Clinical Senior Lecturer in Renal Medicine, Southampton University. which we consider could lead to a reduction in overall dialysis costs.

\section{Methods}

\section{Kiil/Tank System}

The layout of this system is shown in Fig. 1. A list of the equipment required and the costing of individual items are shown in Table I. The 448 litres of dialysate are made in a $500-1$. tank into which 12.81 . of Ilford's concentrate $(\times 35)$ are added to water softened by a Permutit D.R.2 softener. The dialysate concentration is checked by measuring its conductivity with a portable conductivity meter. A Watson-Marlow EL3N pump constantly recirculates and mixes the dialysate. The same pump also delivers dialysate to the bedside monitor. The dialysate is prepared at room temperature and de-aeration is achieved by a system very similar to that described by Parsons and Meff: 7 (1969). The dialysate is warmed to body temperature by a Tecam Temp-unit attached to the bedside monitor. From here the dialysate goes through a flow meter and finally to the Kiil kidney. The effluent dialysate discharges into a floor-level drain. All connecting tubing is of clear plastic beverage hose of varying

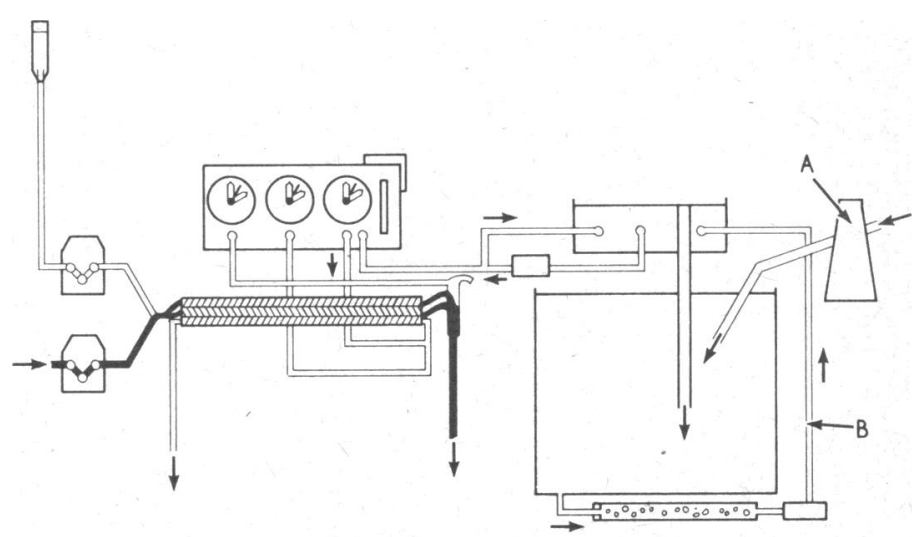

FIg. 1.-Schematic diagram of $\mathrm{Kiil} / \mathrm{tank}$ system. $\mathrm{A}=\mathrm{W}$ ater softener. 
diameter. Fibreglass sinks have been made to accommodate the Kiil boards for washing purposes.

The reliability of the water-softening unit is checked by the patient with a soft-water-testing kit. Usually the water softener has to be recharged about every second dialysis. For blood pump-assisted dialysis we use our own Silastic blood pump inserts housed in an appropriate track to go with the standard M.H.R.E.88H Watson-Marlow blood pump. A breakdown of the running costs: of each dialysis with the $\mathrm{Kiil} /$ tank system is shown in Table II.

\section{Portsmouth Coil/Tank System}

The layout of this system is shown in Figs. 2 and 3. The itemized apparatus list and costs are shown in Table $I$. Essentially, it consists of a coil dialyser (cuprophane P.T.150) with a Watson-Marlow monitoring system. 280 litres of dialysate are made in a 340-1. tank into which 81 . of Ilford's concentrate $(\times 35)$ are added to softened water. The dialysate conductivity is checked as before. The problem of de-aeration does not arise with this system. The dialysate is heated in the same way as with the Kiil/tank system.

The dialysate flow rate is kept at $400 \mathrm{ml}$./minute and the recirculating pump recirculates through the pail assembly at about $30 \mathrm{l}$./minute. The wooden cabinet houses the dialysate circuitry, which is shown in Fig. 2. A special fibreglass sink is not necessary with this system, an ordinary sink unit being satisfactory. To reduce the cost of coil dialyses we chose to use each coil six times. A breakdown of the funning costs of the individual dialyses on this system is shown in Table II.

Reutilization of Coils.-(1) Wash back blood with 5\% dextrose. (2) Deflate the cuff. (3) Wash through with $1 \%$ formalin supplied from a 10-1. carboy until the effluent is clean as judged by the naked eye. During this procedure the coil is sitting in the canister. (4) When the effluent is clear, clamp venous end and fill with $1 \%$ formalin until an intracoil pressure of $100 \mathrm{~mm} . \mathbf{H g}$ is obtained. Clamp formalin side-arm inlet and all other outlets in the circuit to ensure that the intracoil pressure of $100 \mathrm{~mm}$. $\mathrm{Hg}$ is maintained throughout storage. (5) Remove coil from canister and join arterial and venous ends. (6) The coil and lines are stored in an enclosed bucket containing $1 \%$ formalin at room temperature.

\section{Results}

By February 197024 patients had received regular dialysis treatment from this unit-13 on a Kiil/tank system (Heppell Engineering) and 11 on a coil/tank system (Baxter 145 and 100 cuprophane twin-coils). At the time of writing the number of patients using the Kiil and coil systems at home were eight

TABLE I.-Capital Cost of Kiil/Tank and Coil/Tank Systems

\begin{tabular}{|c|c|c|c|c|c|c|c|c|}
\hline & & & & & & & $\underset{\complement}{\mathrm{Kiil} / \mathrm{Tank}}$ & $\begin{array}{l}\text { Coil/Tank } \\
\text { L s. d. }\end{array}$ \\
\hline \multirow{2}{*}{\multicolumn{2}{|c|}{$\begin{array}{l}\text { Dialyser } \\
\text { Tank assembly and } \mathbf{w} \\
\text { Monitoring } \ldots \\
\text { Sink } \\
\text { Dialysis accessories } \\
\text { Total } . .\end{array}$}} & $\begin{array}{l}\ldots \\
\text { water } \\
. . \\
\ldots \\
.\end{array}$ & $\begin{array}{c}\text { softener } \\
\cdots \\
\ldots \\
\cdots\end{array}$ & $\begin{array}{l}\because \\
\because\end{array}$ & $\begin{array}{l}\because \\
\because \\
\because \\
.\end{array}$ & $\begin{array}{l}. . \\
\because \\
\because \\
.\end{array}$ & $\begin{array}{rrr}546 & 10 & 3 \\
98 & 7 & 10 \\
430 & 19 & 6 \\
21 & 0 & 0 \\
44 & 11 & 2 \\
\end{array}$ & $\begin{array}{rrr}293 & 10 & 2 \\
93 & 12 & 8 \\
430 & 19 & 6 \\
22 & 4 & 0 \\
34 & 12 & 8\end{array}$ \\
\hline & &. & .. & .. & $\ldots$ & $\overline{. .}$ & $\begin{array}{|lll|}1,141 & 8 & 9\end{array}$ & 874190 \\
\hline
\end{tabular}

TABLB II.-Running Cost of 6 Dialyses with the Kiill/Tank and Coil/Tank Systems (Shunt Dialyses Only)

\begin{tabular}{|c|c|c|c|c|c|c|c|c|}
\hline & & & & & & & $\begin{array}{c}\text { Kiil/Tank } \\
f \text { s. d. }\end{array}$ & $\begin{array}{c}\text { Coil/Tank } \\
\qquad \text { s. d. }\end{array}$ \\
\hline $\begin{array}{l}\text { Solutions } \\
\text { Drugs _.ejlines } \\
\text { Membranes/lines } \\
\text { Dressings } \\
\text { Miscellaneous } \\
\end{array}$ & $\begin{array}{l}\cdots \\
\cdots \\
\cdots\end{array}$ & $\begin{array}{l}\cdots \\
\because \\
\cdots \\
\cdots\end{array}$ & $\begin{array}{l}\because \\
\because \\
\because \\
\end{array}$ & $\begin{array}{l}\because \\
\because \\
\because \\
\end{array}$ & $\begin{array}{l}\cdots \\
\cdots \\
\cdots \\
\end{array}$ & $\begin{array}{l}\cdots \\
\cdots \\
\cdots\end{array}$ & $\begin{array}{rrr}11 & 16 & 5 \\
1 & 15 & 0 \\
2 & 17 & 0 \\
3 & 5 & 2 \\
3 & 0 & 0 \\
\end{array}$ & $\begin{array}{rrr}7 & 19 & 4 \\
1 & 7 & 4 \\
10 & 13 & 0 \\
3 & 4 & 4 \\
3 & 0 & 0 \\
\end{array}$ \\
\hline Total & .. &. & $\ldots$ & $\ldots$ & $\ldots$ & $\ldots$ & 22137 & 2640 \\
\hline
\end{tabular}

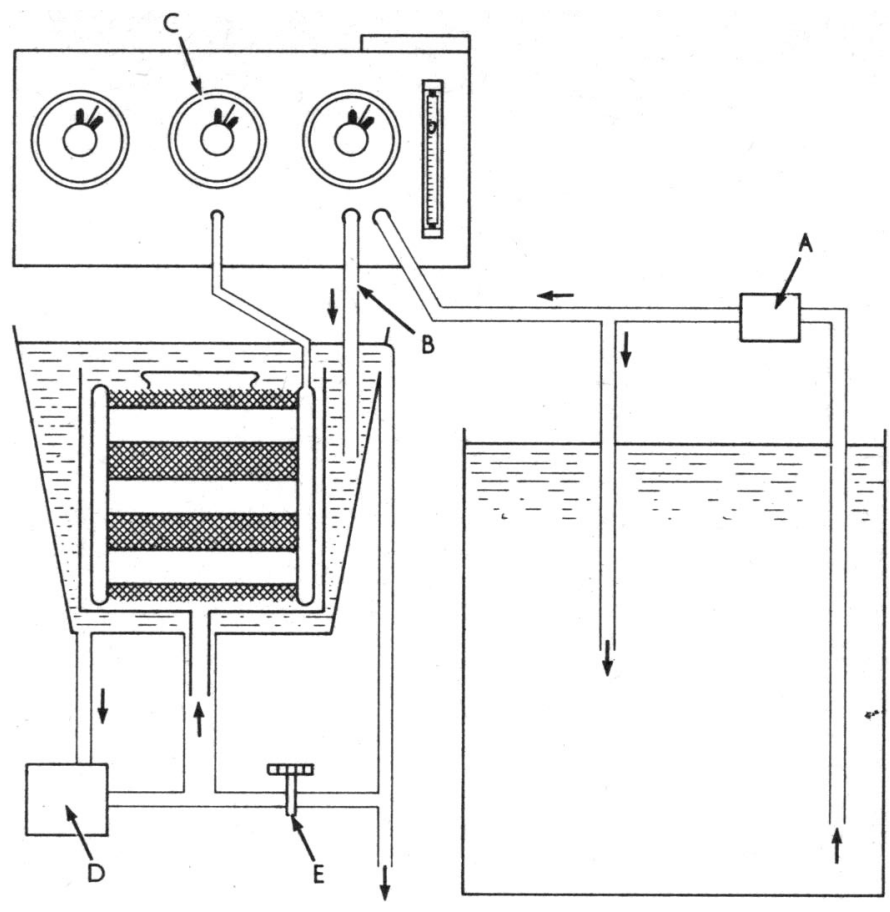

FIG. 2.-Schematic diagram of Portsmouth coil/tank system. $A=$ Supply pump to monitor and recirculator of tank dialysate. $B=$ Supply to pail assembly. $C=$ Centre dial connected to cuff. $D=$ Recirculation pump of pail assembly. $E=$ Drain valve.

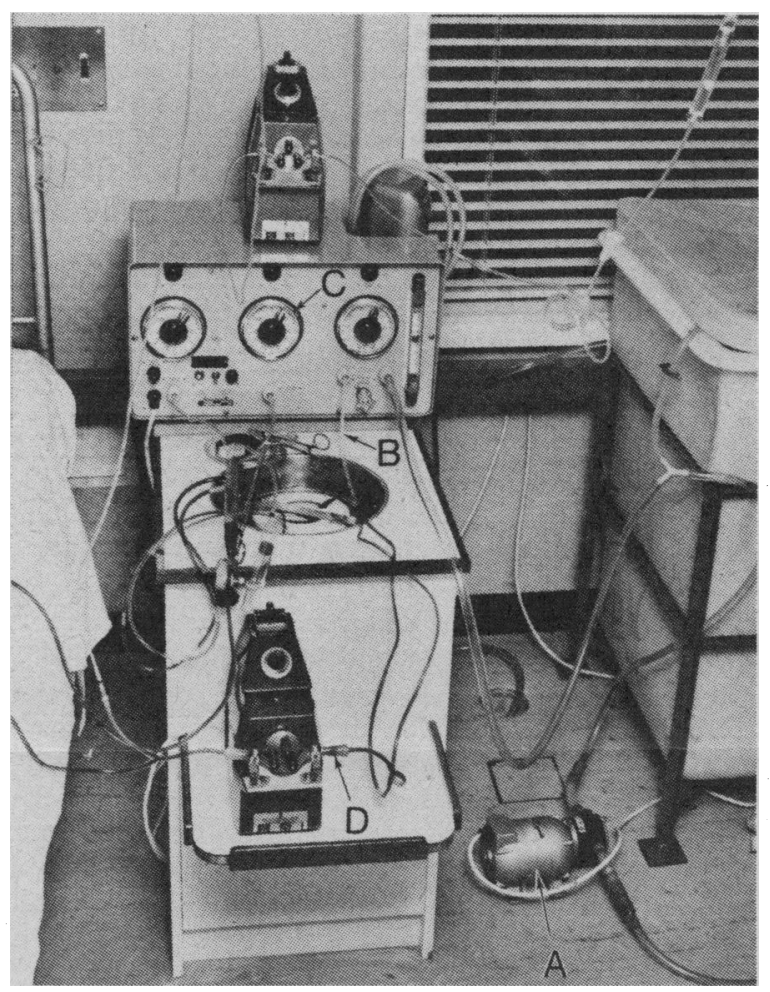

FIG. 3. $-A=$ Supply 'pump to monitor and recirculator of tank dialysate. $B=$ Supply to pail assembly, $C=$ Centre dial; monitors cuff pressure. $D=$ Hospital-made blood pump insert.

and four, respectively. This represents a total experience of 1,477 hospital (82 patient-months) and 735 home (77 patientmonths) Kiil/tank dialyses. Similarly, 898 hospital (63 patientmonths) and 396 home (38 patient-months) coil/tank dialyses have been completed. The first patients sent home on a coil system were using a Baxter recirculation single-pass machine, but recently the latter has been substituted by the Portsmouth coil/tank adaptation. All patients have been dialysed twice 
weekly, on the Kiil kidney for two periods of 12 hours and on the coil kidney for two periods of nine hours.

\section{Blood Replacement}

The predialysis and postdialysis blood chemistry figures for the two groups of patients were very similar (Table III). TABle III.-Blood Analysis. $\begin{gathered}\text { Mean Figures for 1,186 Kiil and } 807 \text { Coil } \\ \text { Dialyses }\end{gathered}$

\begin{tabular}{|c|c|c|c|c|c|c|c|c|}
\hline \multirow{2}{*}{ 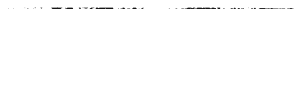 } & & & & \multicolumn{2}{|c|}{ Kiil/Tank } & \multicolumn{2}{|c|}{ Coil/Tank } \\
\hline & & & & & Pre* & Post & Pre* & Post \\
\hline $\begin{array}{l}\text { Urea (mg./100 ml.) } \\
\text { Bicarbonate (mEq/1.) } \\
\text { Potassium (mEq/1.) } \\
\text { Calcium (mg./100 } \mathrm{ml} .) \\
\text { Phosphate (mg./100 ml.) } \\
\text { Creatinine (mg./100 ml.) } \\
\text { Uric acid (mg./100 ml.) } \\
\text { Serum iron }(\mu \mathrm{g} . / 100 \mathrm{ml} .) \\
\text { Haemoglobin }(\mathrm{g} . / 100 \mathrm{ml} .)\end{array}$ & $\begin{array}{l}\cdots \\
\cdots \\
\cdots \\
\cdots \\
\cdots \\
\cdots\end{array}$ & $\begin{array}{l}\cdots \\
\cdots \\
\cdots \\
\cdots \\
\cdots \\
\cdots \\
\cdots\end{array}$ & $\begin{array}{l}\cdots \\
\cdots \\
\cdots \\
\cdots \\
\cdots \\
\cdots \\
\cdots\end{array}$ & $\begin{array}{l}\cdots \\
\cdots \\
\cdots \\
\cdots \\
\cdots \\
\cdots \\
\cdots\end{array}$ & $\begin{array}{l}174 \\
22 \\
5 \cdot 0 \\
9 \cdot 9 \\
6 \cdot 0 \\
17 \\
9 \cdot 0 \\
88 \\
6.9\end{array}$ & $\begin{array}{l}57 \\
25 \\
3 \cdot 6 \\
= \\
= \\
= \\
=\end{array}$ & $\begin{array}{c}172 \\
24 \\
5 \cdot 2 \\
10 \\
6 \cdot 0 \\
15 \cdot 7 \\
8 \cdot 9 \\
68 \\
6 \cdot 6\end{array}$ & $\begin{array}{l}58 \\
28 \\
3 \cdot 7 \\
= \\
= \\
= \\
=\end{array}$ \\
\hline
\end{tabular}

* Predialysis.

†Postdialy

B. First six dialyses have been omitted from each patient to allow for stabilization.

Blood transfusions were uncommon; two patients required 4 units each on the Kiil and four patients required 2 units each on the coil. After nephrectomy one patient on the Kiil system required 12 units of blood for refractory anaemia; another patient required 4 units for gastrointestinal losses. Blood losses with both methods have been estimated (Evans, Clarkson, and Curtis, 1967) and an average blood loss of $4 \mathrm{ml}$. and 7-8 ml. per dialysis has been found for Kiil and coil dialyses, respectively. Both these losses and differences are acceptable, since most patients who have been on dialysis for more than one year have not required transfusion and the haemoglobin values in both groups have been strictly comparable.

\section{Liver Function Tests}

All patients have had their blood screened on two occasions for Australia antigen and have all been negative. Liver function tests have been repeated at monthly intervals on all patients; no cases of anicteric or clinical hepatitis have occurred among our patients or staff. One patient developed cholestatic jaundice as a result of taking the contraceptive pill Enovid, which slowly resolved on stopping the drug.

\section{Clinical Progress}

The comparative medical progress made by the two groups of patients is shown in Table IV. In ten of the thirteen patients being treated with a Kiil dialyser the blood pressure improved, returning completely to normal in nine, remaining static in three. Similarly, of those treated by the coil dialyser, seven had shown improvement, some of these to complete normality, while one patient had actually deteriorated. Those patients with heart failure in both groups improved consider-

TABle IV.-Synopsis of Medical Progress

\begin{tabular}{|c|c|c|c|c|c|c|c|c|}
\hline & \multicolumn{4}{|c|}{ Kiil (13) } & \multicolumn{4}{|c|}{ (Coil 11) } \\
\hline & \multirow{2}{*}{ Normal } & \multicolumn{3}{|c|}{ Abnormal } & \multirow{2}{*}{ Normal } & \multicolumn{3}{|c|}{ Abnormal } \\
\hline & & $\operatorname{Imp}$. & Static & Det. & & Imp. & Static & Det. \\
\hline $\begin{array}{l}\text { Blood pressure (normal } \\
\text { diastolic } 90 \mathrm{~mm} . \mathrm{Hg} \text {.) }\end{array}$ & 9 & 10 & 3 & - & 7 & 7 & - & \\
\hline $\begin{array}{c}\text { Requiring } \\
\text { hypotensive }\end{array}\left\{\begin{array}{l}\text { Yes } \\
\end{array}\right.$ & 2 & 1 & 3 & - & 1 & 3 & 二 & 1 \\
\hline $\begin{array}{l}\text { treatment } \\
\text { Heart failure } \ldots \\
\text { E.C.G. No } \\
\text { Heart size }\end{array}$ & $\begin{array}{r}7 \\
12 \\
5\end{array}$ & $\begin{array}{r}\overline{10} \\
5\end{array}$ & $\overline{-}$ & $\overline{4}$ & $\begin{array}{r}5 \\
10 \\
4\end{array}$ & $\begin{array}{l}2 \\
5 \\
5\end{array}$ & $\frac{7}{2}$ & $\begin{array}{l}\overline{3} \\
2\end{array}$ \\
\hline $\begin{array}{c}\text { graphic assessment) } \\
\text { Neuropathy } \ldots\end{array}$ & $\stackrel{6}{2}$ & 5 & 2 & 2 & 7 & 4 & 2 & 3 \\
\hline $\begin{array}{ll}\text { Psyche } & \text {.. }\end{array}$ & 10 & $\frac{1}{5}$ & $\overline{2}$ & $\begin{array}{l}1 \\
1\end{array}$ & $\begin{array}{l}9 \\
9\end{array}$ & $\begin{array}{l}1 \\
3\end{array}$ & 二 & 2 \\
\hline Libido & 11 & 1 & 2 & 2 & 7 & 1 & - & - \\
\hline
\end{tabular}

Imp. = Improved

Det. $=$ Deteriorated (this may be permanent or temporary). ably, but four and three patients in the Kiil and coil groups, respectively, deteriorated temporarily. These episodes were not related to failures in dialysis technique but rather to the aberrant ways of the patients concerned. Two patients on the coil system had episodes of pericarditis, one a proved Coxsackie B viral pericarditis and another an assumed viral pericarditis associated with general malaise, myalgia, and pleurisy. One patient on a Kiil dialyser also had pericarditis of indeterminate aetiology.

\section{Blood Chemistry}

All patients were dialysed against a bath calcium of 3.1 $\mathrm{mEq} / \mathrm{l}$. (Wing, 1968). Abnormalities of calcium and phosphate metabolism were seen in eight patients in each group. The plasma calcium, phosphate, and alkaline phosphatase levels were measured at monthly intervals. In the Kiil and coil groups high plasma phosphate levels-that is, $6 \mathrm{mg} . / 100 \mathrm{ml}$.occurred in six patients in both groups; the calcium phosphate product exceeded 75 in one patient on a Kiil and in two patients on a coil dialyser, and raised plasma calcium levels above $10.5 \mathrm{mg} . / 100 \mathrm{ml}$. occurred in two and in three patients, respectively. In the latter group with calcium abnormalities in one patient the plasma calcium level rose to $14 \mathrm{mg} . / 100 \mathrm{ml}$. and there was nausea and vomiting. This patient and another with a plasma calcium level above 12 mg./100 ml. were dialysed against a low calcium bath (2 $\mathrm{mEq} / 1$ ) over a six-week period until their plasma calcium levels returned to normal.

At the start of treatment clinical evidence of ectopic calcification, such as band keratopathy, conjunctivitis "red eyes" (Berlyne, 1968), ear-drum calcification, and calcinosis cutis, was found in the two patients on Kiil dialysers (both with high plasma phosphate levels, one only with high $\mathrm{Ca} \times \mathrm{P}$ product) and in three patients on coils (two with high plasma phosphate levels, one with high $\mathrm{Ca} \times \mathrm{P}$ product, and one with high plasma calcium). One patient developed hypophosphataemia, plasma phosphate below $2.5 \mathrm{mg} . / 100 \mathrm{ml}$. after 18 months' haemodialysis treatment. The plasma phosphate returned to normal after a further six months' treatmen: without resort to calcium phosphate therapy.

Initial vascular calcification occurred in three patients on a coil and in one patient on a Kiil dialyser. Of the former three patients one had a high plasma calcium level, one a high plasma phosphate level with high $\mathrm{Ca} \times \mathrm{P}$ product, and one normal plasma phosphate and calcium levels, while the later had a high plasma calcium level. Only one patient on a Kiil dialyser showed any radiological evidence of osteodystrophy, and she initially had very high serum phosphate levels and alkaline phosphatase values, but all tended to improve with continued dialvsis.

\section{Neuropathies}

Perioheral neuropathy, a frequent complication of chronic renal failure (Konotey-Ahulu et al., 1965; Curtis et al., 1969), was regularly looked for. Two patients had clinical neuropathy before haemodialysis. One had bilateral symmetrical motor and sensory involvement affecting the legs. Within two months of starting haemodialysis there was a definite deterioration and walking became difficult. At this time his biochemical control was satisfactory. He was dialysed thrice weekly for two months with remarkable clinical improvement though with less improvement in his nerve conduction times. Thereafter he was maintained on twice-weekly dialysis until successful transplantation. At the start of treatment another patient, on a coil dialyser, had tingling paraesthesiae of the hands and feet, absent vibration sense at both ankles, and weakness of both hands. This neuropathy has worsened throughout one year of dialysis treatment. She now has wasting of all small muscles of both hands with a main en griffe deformity. She has also 
required a left lumbar sympathectomy for a peripheral arteriopathy; she may possibly have a collagen disorder. One patient on a coil dialyser lost her ankle tendon reflexes after six months of haemodialysis.

\section{Rehabilitation}

Those patients who either returned to work or were able to carry on with normal household duties were considered completely rehabilitated. On this basis eight patients on the Kiil and six on the coil systems were fully rehabilitated. Most patients were quite satisfied with whichever dialvser they were allocated, learning the techniques without difficulty, except one who had peripheral neuropathy. The training programme for patienis was between eight and ten weeks. Moreover, patients on the coil system were quicker learning the details than those on a Kiil dialysis system. One patient who could neither read nor write was able to carry on home dialysis with a coil/tank system. Most of the coil dialysis patients opted for afternoon and evening dialvsis sessions rather than overnight. Dialysis thus being predominantly during waking hours, the amount of monitoring required was proportionately less than for overnight dialysis.

No significant difference in the number of blood leaks between coil and Kiil dialysers was noted-an incidence of 3.1 and $1.5 \%$ respectively. Any leaks which did occur always appeared early during a dialysis session and were not related to reuse of either type of kidney.

\section{Disequilibrium Syndrome}

The freauency of any symptoms of diseauilibrium with either system at home was very much less (Table V). Within

TABLE V.-Frequency of Disequilibrium Syndrome Symptoms

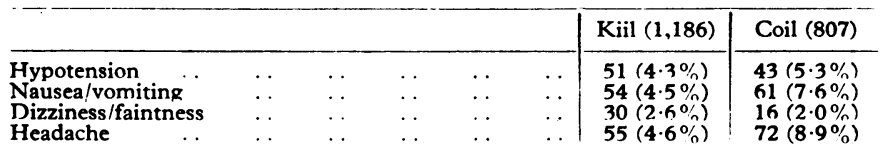

each group one or two patients have accounted for nearly all the disequilibrium phenomena recorded. Again none of the symp toms was related to reusage of either type of kidney. Pyrexial reactions-that is, greater than $99.5^{\circ} \mathrm{F}$. $\left(37.5^{\circ} \mathrm{C}\right.$.) were slightly more common with coil than with Kiil dialvsers, the incidence being 8.5 and $5.5 \%$, respectively. The incidence of such pyrexial episodes was equally distributed between the first and the second half of individual dialysis sessions and was not related to reusage of either type of kidney. Furthermore, no correlation was found between positive blood cultures and pyrexial episodes. Nearly all these pyrexial episodes were unassociated with any other symptoms and for the most part were transient or, at most, lasting two to three hours.

With both systems the number of home dialyses that were interrupted owing to technical failures was eight out of 915 . Usually the cause of the trouble was readily apparent to the patient, who was able to indicate to the unit technician precisely what replacement was required. Maintenance visits were six-monthly and the average number of extra visits made by the technician were 0.8 per patient per year. A complete service takes about one hour with either system.

\section{Discussion}

The merits of Kiil and coil dialysers have been compared and there has been little to choose between them. Though patients on Kiil dialysers were marginally better rehabilitated than those on coils, the latter had a shorter dialysis session with greater ease of preparation and the advantage of using a prepacked and presterilized dialyser. Until recently Kiil kidneys have held the field, mainly because they alone could be used in the home with safety. It has been argued that coils were more expensive and carried the risk of increased blood losses and a higher incidence of disequilibrium symptoms.

For safety reasons engineers have devised elaborate monitoring systems, which are expensive, complex, and often bewildering to the patient. The prerequisites of haemodialysis are simplicity, safety, cheapness, reliability, easy replacement (Kaye, McDade, Comty, 1969), and a high patient acceptability. In Portsmouth we have a reliable coil/tank system, the capital cost of which, for the first time in this cc:-ntry, is under $£ 1,000$. Elaborate proportioning and monitoring systems require expert maintenance, and such expertise is not required in maintaining either of our systems in hospital or home.

We have used tanks exclusively for dialysate delivery and in both systems found them convenient and simple. The dialysate in the tank is cold, and this precludes infection of the dialysate. With the tank system haemodialysis is independent of mains water pressure, and this can be an advantage where the mains pressure is low. Pollution of the mains water by back suction cannot occur, since the softener is remote from the dialysis system during actual dialysis. Nevertheless, we consider it wise to install a non-return valve on the mains wa ${ }^{+}$er supply.

It is held that a tank system puts too much responsibility and stress on the patient. Great care is required in preparing the dialvsate and the procedure is both lengthy and laborious. Our results show that patients find no difficulty in measuring the conductivity of their own dialysate. The difference in preparation time between a tank and an automatic system is abnut 15 minutes in favour of the latter.

Onlv one patient had to be classified as a "failed home dialysis case." She was on a Kiil dialyser and had managed reasonably well when in hospital. After four months of home dialysis she became increasingly apprehensive and had hysterical outbursts during dialvses. She was brought back on to hospital dialysis, which she tolerated well.

It has now been established that coils can be reutilized without risk of infection, without impairment of efficiency, and without increasing the risk of blood losses (Smyth, Clark, and Dawborn, 1969). Initially we used each coil three times to make the cost reasonable (Table II), but recently we have used them safely six times over (Smyth et al., 1969).

Our patients are not given routine blood transfusions, and the number required in each groun was similar and verv low. The source of the losses which did occur could not be found and they did not relate to over-anticoagulation. All other blood transfusions were given to meet anaesthetic reauirements for bilateral nephrectomy. Thus blood transfusion requirements in our patients were not related to the tvne of dialyser used.

\section{Complications}

Though there were three episodes of pericarditis, none was related to the type of dialyser used. All patients had sixmonthly skeletal surveys to detect evidence of renal osteodystrophy. Only one patient had evidence of this before haemodialysis and, though still detectable after one year's treatment, her plasma calcium, phosphate, and alkaline phosnhatase levels had returned to normal. Similarly, sixmonthly vascular radiological surveys to detect extension or appearance of vascular calcification showed no progress in existing lesions or the appearance of new ones; the degree of band keratopathy remained unchanged. Metastatic calcification is likely to occur if the $\mathrm{Ca} \times \mathrm{P}$ product exceeds 75 (Stanbury, 1967; Berlyne, 1968; Curtis et al., 1969), but in our patients the correlation was not clear-cut. Patients with high plasma phosphate levels received aluminium hydroxide tablets (3-6 g./day) from the outset of treatment until plasma phosphate levels had been controlled, usually after two to three months. In some patients this took as long as six months. Three patients - two on coils and one on a Kiil-all of whom showed ectopic calcification from the start, had persistently 
high plasma phosphate levels; these were improved by increasing the number of dialysis hours per week and using the higher dose of aluminium hydroxide.

One patient developed hypophosphataemia of unknown cause, but this resolved spontaneously over a six-month period. There was no evidence of bone disease or ectopic calcification. In all patients with plasma calcium abnormalities the levels returned to normal within six months of starting treatment (Wing, Curtis, Eastwood, Smith, and de Wardener, 1968). Progressive bone disease, increasing metastatic calcification, and acute arthritis were not a problem; this is similar to the experience of Curtis et al. (1969), but contrasts with others (Schreiner, Maher, Freeman, and O'Connell, 1967; Hampers and Schupak, 1967).

The relative infrequence of neurological complications in our grouv may be related to their being taken on early for haemodialysis (Scribner, 1967). Slightly more pyrogen reactions occurred with coil than with Kiil dialysers, most being the typical early reactions but rarely associated with rigors. To determine a cause for these episodes numerous blood cultures, dialysate cultures, and cultures from membranes, lines, and various parts of the equipment were carried out but failed to yield any positive correlations. Positive blood cultures were obtained with equal frequency in patients with pyrogen reactions as in those without; reuse of either type of dialyser was not responsible.

Patients being treated for acute renal failure and reauiring haemodialysis, particularly with coil dialysers, often show features of the disequilibrium syndrome (Kennedy, Linton, Luke, Renfrew, and Dinwoodie, 1964) and increased tendency to the rebound phenomenon (Shackman, Chisholm, Holden, and Pigott, 1962). The incidence of disequilibrium symotoms, however, was the same with both dialysers, the starting blood ureas in the two groups being very similar. Thus efficient dialysis over a shorter period of time can be achieved without disadvantages.

\section{Adaptation of Homes}

Our home adaptation requirements (Table VI) were similar to those of Wright, Goldsmith, and Semple (1969). Home adaptations should be such that any currently available kidney-monitoring system can be installed. This has not been our experience when putting our equipment into houses adapted by other units. Since many of our patients live in council property, when one has been successfully transplanted another in that area can be moved into the house, thus reducing the number of houses that have to be adapted. Our $\mathrm{Kiil} /$ tank system requires more floor area than the coil/tank system, 100 sq. ft. $\left(9.3 \mathrm{~m}^{2}{ }^{2}\right)$, and 80 sq. ft. $\left(7.4 \mathrm{~m} .{ }^{2}\right)$, respectively. With the coil/tank system the small third bedroom of many three-bedroomed houses is sufficient. The cost of such adaptations should not exceed $£ 200$ (Wood and Lee, 1970).

The Kiil/tank system when fully loaded weighs about $550 \mathrm{~kg}$. Even so, when this has been installed in an upstairs bedroom

\section{TABLB VI.-Home Dialysis Adaptation Specification}

(1) Electricity

(b) Four 13-A power points.

(c) 2 or $1.5 \mathrm{~kW}$ wall heater with pull switch (as for bechroom requirements).

(d) Centre fluorescent strip lighting, 4 or $5 \mathrm{ft}$. (122 or $152 \mathrm{~cm}$.) long, with pull

switch to bedside.

(e) Note that the Blectricity authority will make allowances for electricity (2) Plumbing

(b) Wast cold supply to sink; hose fitting on cold tap.

(c) Separand overflow outlets from sink to floor drain.

(c) Separate cold supply to water softener.

(d) Permanent waste and overflow fitting from sink to floor drain.

(f) Soft-water lead-clad drain.

$(61 \mathrm{~cm}$. (g) 1 in. $(2 \cdot 5 \mathrm{~cm}$.) diameter $\mathbf{P}$.V.C. drain. drain from water softener direct to floor
drain.

(3) Flooring and Walls

(a) Vinyl flooring with waterproof sealing.

(b) 4 in. (10 cm.) cove finish at walls, 1 in. $(2.5 \mathrm{~cm}$.) door threshold.

(4) Walls and ceiling to be covered with two coats of white emulsion.

Normal bedside installation. we have not had to reinforce the joists. The problem is even less likely with the Portsmouth coil system, which when fully loaded weighs about $350 \mathrm{~kg}$. Though tank systems can be messy, with a risk of flooding the house, this has not occurred with our patients.

In neither system have we incorporated a blood leak detector. Blood leaks with a Kiil system tend to occur at the beginning of dialysis (Shaldon, 1968) and the same is true with the coil dialyser. Though at first considered mandatory for regular dialysis treatment, many workers (Grimsrud, Cole, Eschbach, Babb, and Scribner, 1967; Shaldon, 1968; Kaye et al., 1969) have deleted them from routine use. We set our gauges, venous and negative pressure, within narrow limits; thus an alarm would sound if major blood volume changes occurred after a large blood leak.

As donor material becomes more available dialysis may become more appropriate to the hospital than to the home. Each hospital bed can be used twice per 24 hours with a coil system, but this is not possible with the conventional Kiil system.

We have described two systems which are efficient, safe, and cheap. Our present capital costs show that we can treat three patients for the price of one treated with some of the more expensive automatic proportioning equipment (Shaldon, 1966; Baillod, Comty, Crockett, and Shaldon, 1967).

Our thanks are due to Mr. R. J. MacLean, of the photographic department, Royal Portsmouth Hospital, for the preparation of the schematic diagrams and for photographing the apparatus.

Detailed breakdown of the information given in Tables I and II is obtainable on request.

Requests for reprints should be sent to Dr. H. A. Lee, St. Mary's General Hospital, Milton Road, Portsmouth.

REFERENCES

Baillod, R. A., et al. (1966). In European Dialysis and Transplant Association: Proceedings of the 2nd Conference on Renal Failure and Replacement of Renal Function, ed. D. N. S. Kerr, p. 99. Amsterdam, Excerpta Medica.

Baillod, R. A., Comty, C., Crockett, R., and Shaldon, S. (1967). In Replacement of Renal Function: Proceedings of the 3rd Conference of the European Dialysis and Transplant Association, ed. D. N. S. Kerr, p. 126. Amsterdam, Excerpta Medica.

Berlyne, G. M. (1968). Lancet, 2, 366.

British Medical fournal, 1969, 3, 485.

Curtis, J. R., et al. (1969). Quarterly fournal of Medicine, 38, 49.

Evans, D. B., Clarkson, E. M., and Curtis, J. R. (1967). British Medical fournal, 4, 651 .

Grimsrud, L., Cole, J. J., Eschbach, J. W., Babb, A. L., and Scribner, B. H. (1967). Transactions. American Society for Artificial Internal Organs, $13,1$.

Hampers, C. L., and Schupak, E. (1967). Long Term Haemodialysis. New York, Grune and Stratton.

Kaye, M., McDade, D., and Comty, C. (1969). In Dialysis and Renal Transplantation: Proceedings of the 5 th Conference of the European Dialysis and Transplant Association, ed. D. N. S. Kerr, p. 56 . Amsterdam, Excerpta Medica.

Kennedy, A. C., Linton, A. L., Luke, R. G., Renfrew, S., and Dinwoodie, A. (1964). Lancet, 1, 790

Konotey-Ahulu, F. I. D., et al. (1965). British Medical fournal, 2, 1212.

Kulatilake, A. E., Vickers, J., and Shackman, R. (1969). British Medical Fournal, 3, 447.

Parsons, F. M., and Meffan, P. (1969). In Dialysis and Renal Transplantation: Proceedings of the 5 th Conference of the European Dialysis and Transplant Association, ed. D. N. S. Kerr, p. 314. Amsterdam, Excerpta Medica.

Schreiner, G. E., Maher, J. F., Freeman, R. B., and O'Connell, J. M. (1967) In Proceeding of the 3rd International Congress of Nephrology, ed. G. E. Schreiner, vol. 3, p. 316. Basle, Karger.

Scribner, B. H. (1967). In Renal Disease, ed. D. A. K. Black, 2nd edn., p. 446. Oxford, Blackwell Scientific.

Shackman, R., Chisholm, G. D., Holden, A. J., and Pigott, R. W. (1962) British Medical fournal, 2, 355 .

Shaldon, S. (1966). Postgraduate Medical fournal, 42, May Suppl.

Shaldon, S. (1967). In Replacement of Renal Function: Proceedings of the 3rd Conference of the European Dialysis and Transplant Association, ed. D. N. S. Kerr, p. 143. Amsterdam, Excerpta Medica.

Shaldon, S. (1968). Lancet, 1, 520.

Smyth, J. L., Clark, R. R., and Dawborn, J. K. (1969). Medical Fournal of Australia, 2, 183.

Stanbury, S. W. (1967). In Renal Disease, ed. D. A. K. Black, 2nd. edn., p. 665. Oxford, Blackwell Scientific.

Wing, A. J. (1968). British Medical fournal, 4, 145.

Wing, A. J., Curtis, J. R., Eastwood, J. B., Smith, E. K. M., and de Wardener, H. E. (1968). British Medical fournal, 4, 150.

Wood, S. E., and Lee, H. A. (1970). Municipal fournal, 78, 1499.

Wright, F. K., Goldsmith, H. J., and Semple, A. B. (1969). British Medical fournal, 1, 701. 